\title{
TEORI EKONOMI DAVID RICARDO, THOMAS MALTHUS, JEAN BAPTISE SAY
}

Oleh

\author{
Devita Ayu Fildayanti//90100118020 \\ email: devita29.akt@gmail.com
}

\section{Teori David Ricardo}

David Ricardo sebagai ahli ekonomi politik Inggris yang lahir pada tahun 1772. Ricardo dianggap menjadikan ilmu ekonomi sebagai ilmu yang kokoh dengan melibatkan ketepatan hitungan matematika. Teori Ricardo yang terkenal adalah teori tentang keunggulan komparatif. Perdagangan tergantung pada keunggulan komparatif atau efisiensi relatif dari pada keunggulan absolut. Negara akan cenderung menjual barangnya yang relatif lebih efisien dalam produksinya. Sehingga melalui spesialisasi, setiap negara akan memperoleh keuntungan dari perdagangan luar negeri (Atmanti, 2017). Teori perdagangan klasik David Ricardo mengasumsikan setiap negara melakukan spesialisasi secara penuh pada sektor-sektor yang memiliki keunggulan komparatif (Kurnia, 2004).

Dalam teori keunggulan komparatif, negara dapat tetap melakukan perdagangan walaupun salah satu negara tidak memiliki keunggulan absolut atau dengan kata lain memiliki kerugian absolut terhadap negara lain dalam memproduksi dua barang. Secara umum David Ricardo mendasarkan teorinya pada sejumlah asumsi yang disederhanakan, yaitu hanya terdapat dua negara dan dua barang, perdagangan bersifat bebas, terdapat mobilitas tenaga kerja yang sempurna di dalam negara namun tidak ada mobilitas antara dua negara, biaya produksi konstan, tidak ada biaya transportasi, tidak ada perubahan teknologi (Sa'idy, 2013).

\section{Teori Thomas Robert Malthus}

Thomas Malthus dalam karyanya Essay of the Principles of Population yang diterbitkan pada tahun 1798 menyatakan ketidakseimbangan antara pertumbuhan penduduk dan produksi pangan dimana peningkatan jumlah penduduk jauh lebih besar dari pada peningkatan produksi pangan yang dihasilkan 
alam (Kabul, 2019). Malthus menekankan pentingnya untuk melakukan pembatasan laju perkembangan populasi penduduk. Pertumbuhan penduduk mengakibatkan pertambahan kebutuhan manusia akan barang dan jasa.

Menurut Thomas Robert Malthus, penduduk bertambah menurut deret ukur $(2,4,8,16,32$, dan seterusnya), sedangkan makanan bertambah menurut deret hitung (1, 2, 3, 4, 5, 6, dan seterusnya). Akibatnya jumlah barang dan jasa, termasuk makanan, tidak seimbang dengan jumlah penduduk (Muna, 2020). Dari teorinya itu, Malthus memberikan kesimpulan dan solusinya dengan dua hal utama, pertama pembukaan tanah lebih banyak dan dengan menganjurkan pertanian sebesar-besarnya, kemudian jika cara ini dipandang masih belum efektif dalam mengatasi kerawanan pangan, maka yang kedua adalah dengan pengendalian pertumbuhan penduduk (Subair, 2015).

\section{Teori Jean Baptiste Say}

Say berasal dari Perancis, yang sangat memuja Adam Smith. Say berjasa dalam melakukan kodifikasi pemikiran Smith dan dirangkum dalam bukunya Traite d'Economie Politique pada tahun 1803, dan mendukung faham laissez faire. Kontribusi Say yang paling besar pada mazhab klasik adalah setiap penawaran akan menciptakan sendiri permintaannya atau dikenal dengan supply creates its own demand. Pendapat ini sering disebut dengan Say's Law. Hukum Say didasarkan pada asumsi bahwa nilai produksi selalu sama dengan pendapatan. Dengan demikian, dalam keadaan seimbang produksi cenderung menciptakan permintaannya sendiri (Atmanti, 2017).

Perilaku kapitalis adalah laissez faire et laissez le monde va de lui meme (biarkan ia berbuat dan biarkan ia berjalan, dunia akan mengurus diri sendiri). Maksudnya biarkan sajalah perekonomian berjalan dengan wajar tanpa intervensi pemerintah, nanti akan ada suatu tangan tak terlihat (invisible hands) yang akan membawa perekonomian tersebut ke arah keseimbangan. Jika pemerintah campur tangan maka pasar akan mengalami distorsi yang akan membawa perekonomian pada ketidakefisienan dan ketidakseimbangan (Kamiruddin, 2018). 


\section{DAFTAR PUSTAKA}

Atmanti, H.D. (2017). Kajian Teori Pemikiran Ekonomi Mazhab Klasik dan Relevansinya pada Perekonomian Indonesia. Jurnal Ekonomi dan Bisnis. 2(2), 511-524.

Kabul, L. M. (2019). MANAJEMEN PEMBANGUNAN KEPENDUDUKAN: KOREKSI TERHADAP TEORI MALTHUS. 13(2), 317-325.

Kamiruddin, \& Iddris Parakkasi. (2018). ANALISIS HARGA DAN MEKANISME PASAR DALAM PERSPEKTIF ISLAM. LAA MAISYIR. 5(1), 107-120.

Kurnia, A.S. (2004). PERSPEKTF ALTERNATIF PERDAGANGAN DAN PEMBANGUNAN, ANTARA OPTIMISME DAN PESIMISME PERDAGANGAN BEBAS: SUATU TINJAUAN KRITIS TERHADAP TEORI PERDAGANGAN NEO KLASIK. Jurnal Dinamika Ekonomi dan Bisnis. 1(1), 1-13.

Muna, T. I., \& Qomar, M. N. (2020). Relevansi Teori Scarcity Robert Malthus Dalam Perspektif Ekonomi Syariah. SERAMBI: Jurnal Ekonomi dan Bisnis Islam. 2(1), 1-14.

Sa'idy, I.B. (2013). ANALISIS DAYA SAING KOMODITAS TEKSTIL DAN PRODUK TEKSTIL INDONESIA DI AMERIKA SERIKAT. Economics Development Analysis Journal. 2(4), 269-276.

Subair. (2015. RELEVANSI TEORI MALTHUS DALAM DISKURSUS KEPENDUDUKAN KONTEMPORER. 9(2), 96-110. 